\title{
sciendo
}

10.2478/aucft-2019-0016

\section{PHYSICOCHEMICAL CHARACTERISTICS AND NUTRITIONAL COMPOSITIONS OF SOME DATE (PHOENIX DACTYLIFERA L.) FRUIT CULTIVARS}

\author{
- Research paper -
}

\author{
Ouarda DJAOUDENE, Mostapha BACHIR BEY ${ }^{1}$, Hayette LOUAILECHE
Département des Sciences Alimentaires, Faculté des Sciences de la Nature et de la Vie, Laboratoire de Biochimie Appliquée, Université de Bejaia, 06000, Bejaia, Algérie

\begin{abstract}
A comparative study was carried out for eight mature date fruit cultivars to assess physicochemical and nutritional values. Results showed that fruit and flesh weights and seed sizes indicated wide diversity among studied cultivars. The highest $\mathrm{pH}$, acidity, and ash levels were obtained from Tazizaout and Oukasaba cultivars; protein contents varied from 0.47 (Tazizaout) to $0.31 \mathrm{~g} / 100 \mathrm{~g}$ DM (Delat), while free amino acids concentrations were found between 1.47 (Oukasaba) and $0.79 \mathrm{~g} / 100 \mathrm{~g}$ DM (Tazarzeit). Total carbohydrates were ranged from 96.28 to 84.51 $\mathrm{g} / 100 \mathrm{~g}$ DM. The date is low in fat, the highest concentration was $0.11 \mathrm{~g} / 100 \mathrm{~g}$ DM. Principal Component Analysis indicated that Ourous and Delat cultivars have specific characteristics and can be distinguished from the other cultivars.
\end{abstract}

Keywords: Date palm, cultivar, physicochemical characteristic, nutritional composition, biodiversity

\section{INTRODUCTION}

Date palm (Phoenix dactylifera L.) is considered among the oldest cultivable crop that was extensively grown in northern Africa and Middle East. This fruit is a berry including one-seeded that is surrounded by a relatively hard endocarp, then by fleshy mesocarp and finally by a thin epicarp (Ahmed et al., 1995). The date is considered to be an important subsistence crop in arid and semi-arid regions and plays an important socioeconomic strategy for many countries (Chandrasekaran and Bahkali, 2013). More than 2000 cultivars have been recorded around the world, but only a few of them have been used for their agricultural productivity and fruit quality (Mrabet et al., 2008).

The Date plays an important role in the social life of the people both in their diet and medicinally. This fruit is well known for its numerous health properties; it is recommended for the prevention and treatment of several diseases such as coronary heart-related dysfunctions, constipation, cancer, etc. (Sulieman et al., 2012).

The Date fruit is considered as the main crop produced in Algeria; with 1058559 tons harvested in 2017, it ranks the third worldwide (FAOSTAT, 2018). In addition to its leading economic place, dates are an integral part of Algeria diet and are

Received: 05.07.2019.

Accepted in revised form: 18.11.2019 usually consumed either fresh or sun-dried as such or with milk. In order to elaborate processed products with high value-added, dates are consumed as syrup, jellies, pickles, paste, jams, and are used in many bakery or confectionery products together with chocolate, coconut, honey, vinegar, and others (Ghnimi et al., 2017).

This fruit considered as a good source of numerous nutrients (simple and complex sugars, minerals, antioxidants, etc.) and provide rapid energy due to their high carbohydrates content. The most are fructose and glucose, which are easily assimilated by the human body (Myhara et al., 1999). It is established that date composition can vary from cultivars depending on soil and climate conditions and agronomic practices (Al-Farsi et al., 2007).

M'zab oasis of Ghardaia department (southern Algeria) is among the highest date productivity with high biodiversity of date palm in Algeria. However, little scientific knowledge is available on the functional and biochemical composition of date fruits cultivars of this region. It was also revealed that differences in cultivars and locations might also affect the physicochemical characteristics of date fruits. Therefore, because of the growing importance of date fruits crop in Algeria, the current study was performed to evaluate physicochemical characteristics and nutritional

\footnotetext{
${ }^{1}$ Corresponding author. E-Mail address: bachirbeymustapha@gmail.com
} 
compositions of date fruits of eight cultivars ("Ourous, Tazizaout, Tazarzeit, Tazoughart, Ouaouchet, Oukasaba, Delat, and Tamezwert n'telet" native to M'zab oasis) and assess the interrelationships between parameters, using the
Principal Component Analysis, allowing a precise characterization of studied cultivars. This would provide a description of characteristics, serving as a basis for the standardization of the fruit to promote its production and utilization.

\section{MATERIALS AND METHODS}

\section{Plant material}

Eight ripe cultivars of date palm fruits locally known as Ourous, Tazizaout, Tazarzeit, Tazoughart, Ouaouchet, Oukasaba, Delat, and Tamezwert n'telet were harvested in November 2016.Fruits were collected from M'zab oasis in the region of Ghardaia (Southern Algeria). They were selected with similar size, ripening stage, without infection and physical damage. Samples were cleaned, pitted, and crushed with hand grinding mill and kept in polyethylene boxes at $4{ }^{\circ} \mathrm{C}$.

\section{Determination of morphological parameters}

The physical characteristics were measured on 10 randomly harvested fruits. The investigated parameters were fruit size (weight, length, and width), measured using calliper. The length/width ratio was then calculated. Flesh and seed weight (in $\mathrm{cm}$ ) of fruit were determined using an analytical balance (RADWAG model PS $600 / \mathrm{C} / 2$, Poland) and the seed/fruit, flesh/fruit and flesh/seed ratio were determined.

\section{Determination of physicochemical characteristics and nutritional compositions}

Hydrogen potential measurements were performed using a pH meter (Bante model $920, \mathrm{UK}$ ) at $20^{\circ} \mathrm{C}$. Titratable acidity, expressed as a percentage of malic acid equivalent, was determined by titrating with $\mathrm{NaOH}$ solution $(0.01 \mathrm{~N})$ to endpoint $\mathrm{pH}$ of 8.1 \pm 0.20 (ISO 750, 1998). Total soluble solids (TSS) were measured with Abbe Refractometer (Optic system) and expressed as ${ }^{\circ}$ Brix. Ash was obtained by combustion of dates in a muffle furnace (Nabertherm $\mathrm{GmbH}$, Germany) at $550{ }^{\circ} \mathrm{C}$ for 6 hours. Moisture content was determined from $2 \mathrm{~g}$ of homogenized date fruits using a ventilated oven (WTB Binder, 120 Tuttlingen, Germany) at $105^{\circ} \mathrm{C}$ until constant weight. Lipids were extracted with a Soxhlet extractor (Behr Labor Technik, Germany) from $15 \mathrm{~g}$ of date pulp with $150 \mathrm{ml}$ of petroleum ether; fat contents were calculated after the removal of the solvent by evaporation.

The HMF content was recorded as described by White (1979). The sample $(0.5 \mathrm{~g})$ was homogenized with $10 \mathrm{ml}$ of distilled water; $500 \mu \mathrm{l}$ of Carrez I (potassium ferricyanide 15\%) and Carrez II (zinc acetate $30 \%$ ) reagents were added and the volume was completed to $15 \mathrm{ml}$ with distilled water. The supernatant was paper filtered and a volume of 1 $\mathrm{ml}$ of filtrate is put in two test tubes to which $1 \mathrm{ml}$ of distilled water as sample or bisulfite $(0.2 \%)$ as reference are added. The HMF content was calculated according to the following equation: $\operatorname{HMF}(\mathrm{mg} / 100 \mathrm{~g})=\left(\mathrm{A}_{284}-\mathrm{A}_{336}\right) \times 74.85$

$\mathrm{A}_{284}$ and $\mathrm{A}_{336}$ : absorbance values at 284 and 336nm, respectively.

74.85: Specific factor of dilution and conversion. FAA content was estimated according to Yemm et al. (1955) method. FAA were extracted from date pulp with $10 \mathrm{ml}$ of $80 \%$ ethanol, the mixture was incubated at $95^{\circ} \mathrm{C}$ for $20 \mathrm{~min}$, then the extract was separated by centrifugation (Nuve NF 200, Ankara, Turkey). $1 \mathrm{ml}$ of the extract was added to $0.5 \mathrm{ml}$ of citrate buffer $(0.2 \mathrm{M}, \mathrm{pH} 5), 1 \mathrm{ml}$ of potassium cyanide $(0.01 \mathrm{M})$ and $200 \mu \mathrm{l}$ of ninhydrin $(1 \%)$. After $15 \mathrm{~min}$ of incubation at $100^{\circ} \mathrm{C}, 2.3 \mathrm{ml}$ of $60 \%$ ethanol was added to the reaction mixture. The absorbance was measured at $570 \mathrm{~nm}$ and results were expressed as mg leucine equivalent per $100 \mathrm{~g}$ of dry matter (DM) with reference to a calibration curve.

The proline content was determined by the spectrophotometric method described by Bates et al. (1973). $0.1 \mathrm{~g}$ of date pulp was stirred with $10 \mathrm{ml}$ of sulfosalicylic acid (3\%) for $30 \mathrm{~min}$. The extract is recovered after filtration. $0.5 \mathrm{ml}$ of the glacial acetic acid and $0.5 \mathrm{ml}$ of the acid-ninhydrin are added to the assay. The mixture is heated for 60 min in a water bath at $95{ }^{\circ} \mathrm{C}$ (WB 22, Memmert, Osterode, Germany). After cooling, $1 \mathrm{ml}$ of toluene is added and the mixture is centrifuged at 5000 rpm for $10 \mathrm{~min}$. The absorbance of the organic phase is recorded at $520 \mathrm{~nm}$. The total content of proline was determined based on a standard calibration curve prepared using proline.

The method of Bradford (1976) was used for protein determination. Bradford reagent $(2.5 \mathrm{ml})$ was mixed with $0.1 \mathrm{ml}$ of extract and the absorbance was measured at $595 \mathrm{~nm}$ after $5 \mathrm{~min}$ of incubation. Protein concentrations were expressed as $\mathrm{mg}$ of bovine serum albumin (BSA) equivalent per $100 \mathrm{~g}$ of DM using a calibration curve of BSA. Total carbohydrates were determined according to the phenol-sulfuric acid method according to 
Dubois et al. (1956). The diluted sample $(0.5 \mathrm{ml})$ was mixed with $0.5 \mathrm{ml}$ phenol solution (5\%) followed by addition of $2.5 \mathrm{ml}$ concentrated sulfuric acid. The mixture was left at $105^{\circ} \mathrm{C}$ for 5 min prior to measuring absorbance at $490 \mathrm{~nm}$ using a spectrophotometer (Uvline 9400, Secomam, France). The total carbohydrate content was determined based on a standard calibration curve prepared using glucose.

Reducing sugars were determined by the dinitrosalicylic acid (DNS) method (Miller, 1959). DNS reagent $(1 \mathrm{ml})$ was added to $1 \mathrm{ml}$ of the extract, the mixture was heated for $15 \mathrm{~min}$ in a water bath at $95{ }^{\circ} \mathrm{C}$. To stabilize the colour under these conditions, $1 \mathrm{ml}$ of a $40 \%$ Rochelle salt was added to the mixture. The absorbance was measured at $575 \mathrm{~nm}$ and the results were expressed as $g$ of glucose per $100 \mathrm{~g}$ of DM with reference to a calibration curve using glucose as a standard.

\section{Statistical Analysis}

The results are expressed as the average values of three repetitions. To assess the significant differences of physicochemical characteristics among cultivars, analysis of variance with LSD test (Least Significant Difference) was performed using the Statistica software 8 . A probability of 0.05 was considered significant.

To evaluate the relationship between different parameters and cultivars, a Principal Component Analysis (PCA) was conducted using the Statistica software. This statistical method was performed on the variance matrices for each group of parameters (morphological and physicochemical).

The significance of similarities between cultivars was tested to provide a set of weightings that allow studied date palm cultivars to be distinguished.

\section{RESULTS AND DISCUSSION}

\section{Morphological characteristics}

The physical properties of the eight date cultivars were presented in Table 1. Delat cultivar was the weightiest fruit $(9.89 \mathrm{~g})$, while Tazarzeit was significantly lower than the other cultivars $(6.94$ $\mathrm{g})$. The weights of analyzed dates were lower than those reported by Sulieman et al. (2012) for five date palm cultivars grown in Sudan which showed that the highest value was $12.78 \mathrm{~g}$. According to Saeed et al. (2015) study on five date cultivars grown under Sudanese conditions, the fruits Ambrah variety exceed $22 \mathrm{~g}$ that was classified as fruits with the heaviest weight.

Tazoughart had the highest value of seeds weight percentage $(16 \%)$, followed by Delat and Tamezwert $n$ 'telet $(15 \%)$ and the lowest was Ouaouchet cultivar (11\%). Consequently, the flesh/seed ratio varied between cultivars, it was noted from table 1that Tazoughart had the lowest ratio (5.32) and Ourous exhibited the highest ratio (9.14) and considered as the cultivar which highest edible portion.

Delat cultivar had the lengthen fruit $(5.01 \mathrm{~cm})$ followed by Ourous (4.79 cm), Oukasaba had the least fruit length $(3.63 \mathrm{~cm})$ which was statistically lower than all other cultivars. Tazoughart had the highest fruit diameter $(2.17 \mathrm{~cm})$ while Tazarzeit cultivar had the lowest one $(1.81 \mathrm{~cm})$.

The average fruit length was $4.21 \mathrm{~cm}$ which is higher than that reported by Singh et al. (2013) for Omani cultivars, which ranged between 2.70 and $4.07 \mathrm{~cm}$. The average fruit diameter was $1.90 \mathrm{~cm}$ which is lower than Iranian cultivars investigated by (Jahromi et al., 2007), which was in the range between 1.82 and $2.53 \mathrm{~cm}$.

The flesh/fruit ratio was a criterion of date characterization. It indicated from the results of Table 1that the flesh represents about $90-84 \%$ of the whole date weight. The Ourous cultivar seems the best one, followed by Ouaouchet. The flesh/date fruit ratio of these cultivars was very similar to the most well-known Tunisian cultivars Deglet Nour and Horra, which is equal to 90 and $88 \%$, respectively (Amira et al., 2011).

The morphological parameters were important criteria for the differentiation between the studied cultivars. Variations of physical parameters proved significant differences of the fruit characteristics in some date cultivars (Shar et al., 2012).

\section{Determination of physicochemical characteristics and nutritional compositions}

The determination of physicochemical and nutritional compositions of dates is considered as important for storage, processing, and commercialization of dates.

Physicochemical characteristics ( $\mathrm{pH}, \mathrm{TA}, \mathrm{TSS}$, moisture, ash, lipids, HMF, FAA, proline, proteins, carbohydrates and reducing sugars) of eight date cultivars grown in M'zab oasis revealed statistical differences and the results were regrouped in Table 2. 
Table 1. Physical characteristics of studied date cultivars

\begin{tabular}{|c|c|c|c|c|c|c|c|c|}
\hline Parameter & Ourous & Tazizaout & Tazarzeit & Tazoughart & Ouaouchet & Oukasaba & Delat & Tamezwert n'telet \\
\hline $\begin{array}{l}\text { Fruit weight } \\
(\mathrm{g})\end{array}$ & $\begin{array}{l}8.98 \pm \\
0.63^{b}\end{array}$ & $\begin{array}{l}8.31 \pm \\
0.75^{\mathrm{bc}}\end{array}$ & $\begin{array}{c}6.94 \pm \\
1.39^{\mathrm{e}}\end{array}$ & $\begin{array}{c}8.04 \pm \\
0.88^{\mathrm{c}}\end{array}$ & $\begin{array}{l}7.79 \pm \\
0.64^{\mathrm{cd}}\end{array}$ & $\begin{array}{l}7.97 \pm \\
0.85^{\mathrm{c}}\end{array}$ & $\begin{array}{c}9.89 \pm \\
1.06^{\mathrm{a}}\end{array}$ & $\begin{array}{l}7.19 \pm \\
0.74^{\mathrm{de}}\end{array}$ \\
\hline $\begin{array}{l}\text { Flesh weight } \\
(\mathrm{g})\end{array}$ & $\begin{array}{c}8.04 \pm \\
0.53^{\mathrm{a}}\end{array}$ & $\begin{array}{l}7.02 \pm \\
1.17^{\mathrm{b}}\end{array}$ & $\begin{array}{c}5.98 \pm \\
1.39^{\mathrm{c}}\end{array}$ & $\begin{array}{l}6.78 \pm \\
0.80^{\mathrm{bc}}\end{array}$ & $\begin{array}{l}6.87 \pm \\
0.60^{\mathrm{b}}\end{array}$ & $\begin{array}{c}6.93 \pm \\
0.79^{\mathrm{b}}\end{array}$ & $\begin{array}{c}8.31 \pm \\
1.03^{\mathrm{a}}\end{array}$ & $\begin{array}{c}6.05 \pm \\
0.58^{\mathrm{c}}\end{array}$ \\
\hline $\begin{array}{l}\text { Seed weight } \\
(\mathrm{g})\end{array}$ & $\begin{array}{l}0.86 \pm \\
0.14^{\mathrm{de}}\end{array}$ & $\begin{array}{c}1.04 \pm \\
0.15^{\mathrm{c}}\end{array}$ & $\begin{array}{l}1.00 \pm \\
0.20^{\mathrm{cd}}\end{array}$ & $\begin{array}{l}1.28 \pm \\
0.16^{\mathrm{b}}\end{array}$ & $\begin{array}{l}0.86 \pm \\
0.12^{\mathrm{d}}\end{array}$ & $\begin{array}{l}0.97 \pm \\
0.12^{\text {cde }}\end{array}$ & $\begin{array}{c}1.50 \pm \\
0.20^{\mathrm{a}}\end{array}$ & $\begin{array}{c}1.09 \pm \\
0.20^{\mathrm{c}}\end{array}$ \\
\hline $\begin{array}{l}\text { Fruit length } \\
(\mathrm{cm})\end{array}$ & $\begin{array}{l}4.79 \pm \\
1.74^{\mathrm{b}}\end{array}$ & $\begin{array}{c}3.99 \pm \\
1.46^{\mathrm{d}}\end{array}$ & $\begin{array}{l}3.73 \pm \\
2.28^{\mathrm{e}}\end{array}$ & $\begin{array}{l}4.04 \pm \\
1.71^{\mathrm{d}}\end{array}$ & $\begin{array}{l}4.11 \pm \\
2.92^{\mathrm{d}}\end{array}$ & $\begin{array}{c}3.63 \pm \\
1.82^{\mathrm{e}}\end{array}$ & $\begin{array}{c}5.01 \pm \\
3.37^{\mathrm{a}}\end{array}$ & $\begin{array}{l}4.37 \pm \\
2.13^{\mathrm{c}}\end{array}$ \\
\hline $\begin{array}{l}\text { Fruit width } \\
(\mathrm{cm})\end{array}$ & $\begin{array}{c}1.82 \pm \\
0.75^{\mathrm{c}} \\
\end{array}$ & $\begin{array}{c}1.84 \pm \\
0.72^{\mathrm{c}} \\
\end{array}$ & $\begin{array}{c}1.81 \pm \\
1.11^{\mathrm{c}} \\
\end{array}$ & $\begin{array}{c}2.17 \pm \\
1.39^{\mathrm{a}} \\
\end{array}$ & $\begin{array}{c}1.95 \pm \\
1.37^{\mathrm{b}} \\
\end{array}$ & $\begin{array}{l}1.87 \pm \\
1.20^{\mathrm{bc}} \\
\end{array}$ & $\begin{array}{c}1.9 \pm \\
2.29^{\mathrm{bc}} \\
\end{array}$ & $\begin{array}{c}1.9 \pm \\
1.06^{\mathrm{bc}}\end{array}$ \\
\hline $\begin{array}{l}\text { Fruit } \\
\text { Length/width }\end{array}$ & 2.63 & 2.17 & 2.06 & 1.86 & 2.11 & 1.94 & 2.64 & 2.30 \\
\hline Seed/fruit weight & 0.10 & 0.13 & 0.14 & 0.16 & 0.11 & 0.12 & 0.15 & 0.15 \\
\hline Flesh/fruit weight & 0.90 & 0.84 & 0.86 & 0.84 & 0.88 & 0.87 & 0.84 & 0.84 \\
\hline Flesh/seed weight & 9.14 & 6.75 & 5.96 & 5.32 & 8.03 & 7.11 & 5.53 & 5.57 \\
\hline Seed \% & 10 & 13 & 14 & 16 & 11 & 12 & 15 & 15 \\
\hline
\end{tabular}

Each value represents the mean \pm SE. Results within the same line with different letters are statistically different at $\mathrm{p}<0.05$ (ANOVA-LSD test)

Table 2. Proximate chemical composition of the studied date cultivars

\begin{tabular}{|l|c|c|c|c|c|c|c|}
\hline \multicolumn{1}{|c|}{ Date variety } & $\mathrm{pH}$ & $\begin{array}{c}\text { Acidity } \\
(\%)\end{array}$ & $\begin{array}{c}\text { TSS } \\
(\%)\end{array}$ & $\begin{array}{c}\text { Ash } \\
(\%)\end{array}$ & $\begin{array}{c}\text { Moisture } \\
(\%)\end{array}$ & $\begin{array}{c}\text { Fat } \\
(\%)\end{array}$ & $\begin{array}{c}\text { HMF } \\
(\mathrm{mg} / 100 \mathrm{~g})\end{array}$ \\
\hline \multirow{2}{*}{ Ourous } & $6.017 \pm$ & $0.16 \pm$ & $69.12 \pm$ & $1.85 \pm$ & $11.34 \pm$ & $0.043 \pm$ & $0.24 \pm$ \\
& $0.007^{\mathrm{d}}$ & $0.01^{\mathrm{d}}$ & $0.62^{\mathrm{c}}$ & $0.14^{\mathrm{ab}}$ & $0.00^{\mathrm{d}}$ & $0.005^{\mathrm{c}}$ & $0.08^{\mathrm{c}}$ \\
\hline \multirow{2}{*}{ Tazizaout } & $6.73 \pm$ & $0.33 \pm$ & $71.88 \pm$ & $1.80 \pm$ & $14.08 \pm$ & $0.063 \pm$ & $0.16 \pm$ \\
& $0.007^{\mathrm{a}}$ & $0.02^{\mathrm{a}}$ & $0.67^{\mathrm{b}}$ & $0.49^{\mathrm{abc}}$ & $0.16^{\mathrm{cd}}$ & $0.033^{\mathrm{bc}}$ & $0.05^{\mathrm{cd}}$ \\
\hline \multirow{2}{*}{ Tazarzeit } & $6.30 \pm$ & $0.23 \pm$ & $71.53 \pm$ & $1.25 \pm$ & $14.14 \pm$ & $0.037 \pm$ & $0.07 \pm$ \\
& $0.019^{\mathrm{b}}$ & $0.00^{\mathrm{c}}$ & $0.87^{\mathrm{b}}$ & $0.07^{\mathrm{c}}$ & $0.00^{\mathrm{cd}}$ & $0.024^{\mathrm{c}}$ & $0.02^{\mathrm{d}}$ \\
\hline \multirow{2}{*}{ Tazoughart } & $6.05 \pm$ & $0.29 \pm$ & $64.90 \pm$ & $1.40 \pm$ & $14.79 \pm$ & $0.077 \pm$ & $0.14 \pm$ \\
& $0.003^{\mathrm{c}}$ & $0.01^{\mathrm{b}}$ & $0.73^{\mathrm{e}}$ & $0.15^{\mathrm{bc}}$ & $0.46^{\mathrm{cd}}$ & $0.024^{\mathrm{abc}}$ & $0.08^{\mathrm{cd}}$ \\
\hline \multirow{2}{*}{ Ouaouchet } & $6.05 \pm$ & $0.16 \pm$ & $71.29 \pm$ & $1.47 \pm$ & $13.24 \pm$ & $0.103 \pm$ & $0.62 \pm$ \\
& $0.011^{\mathrm{c}}$ & $0.01^{\mathrm{d}}$ & $0.75^{\mathrm{b}}$ & $0.11^{\mathrm{abc}}$ & $0.29^{\mathrm{cd}}$ & $0.005^{\mathrm{ab}}$ & $0.1^{\mathrm{a}}$ \\
\hline \multirow{2}{*}{ Oukasaba } & $5.53 \pm$ & $0.31 \pm$ & $65.01 \pm$ & $1.99 \pm$ & $39.04 \pm$ & $0.09 \pm$ & $0.15 \pm$ \\
\hline \multirow{2}{*}{ Delat } & $0.011^{\mathrm{f}}$ & $0.01^{\mathrm{ab}}$ & $0.16^{\mathrm{e}}$ & $0.00^{\mathrm{a}}$ & $3.92^{\mathrm{a}}$ & $0.014^{\mathrm{ab}}$ & $0.07^{\mathrm{cd}}$ \\
\hline \multirow{2}{*}{ Tamezwert n'telet } & $5.98 \pm$ & $0.23 \pm$ & $67.06 \pm$ & $1.49 \pm$ & $18.27 \pm$ & $0.113 \pm$ & $0.16 \pm$ \\
& $0.010^{\mathrm{e}}$ & $0.00^{\mathrm{c}}$ & $0.94^{\mathrm{d}}$ & $0,14^{\mathrm{abc}}$ & $0.44^{\mathrm{c}}$ & $0.009^{\mathrm{a}}$ & $0.05^{\mathrm{cd}}$ \\
\hline
\end{tabular}

Each value represents the mean \pm SE. Results within the same line with different letters are statistically different at $\mathrm{p}<0.05$ (ANOVA-LSD test)

$\mathrm{pH}$ value of studied cultivars was ranged between 5.49 and 6.73. Our results showed a similar trend to those reported in other date cultivars, who studied chemical compositions of Iranian date palm (Rastegar et al., 2012).

For titratable acidity, significant differences were observed among studied cultivars. The values of titratable acidity varied from $0.16 \%$ observed in Ourous and Ouaouchet to $0.33 \%$ obtained from Tazizaout. Our results were lower than those reported by Hesami and Abdi (2010), who obtained values ranged between 0.36 to $0.50 \%$ for date cultivars grown in Iran, but higher than those reported by Lemine et al. (2014) for Mauritanian cultivars ( 0.03 to $0.14 \mathrm{~g}$ malic acid/100g FW).
These results showed that Tamezwert n'telet had the highest TSS content ( $73.22{ }^{\circ}$ Brix) followed by Tazizaout $\left(71.88^{\circ}\right.$ Brix) and the lowest level was recorded to Tazoughart (64.90 ${ }^{\circ}$ Brix). The TSS values were in good agreement with those reported for the three Tunisian cultivars (Deglet Nour, Alligand, and Kentichi) values ranging between 65 and $75^{\circ}$ Brix (Abbès et al., 2011) and lower than with those measured by Al Tamim (2014) for Saudi and Egyptian date fruits (89 and $91^{\circ}$ Brix). Differences observed were principally due to the cultivar but other parameters can contribute such as climate conditions and harvesting period.

The eight studied cultivars present low percentages of ash (Table 2); the highest level was obtained 
from Oukasaba cultivar (1.99\%) and the lowest one was recorded to Tazoughart cultivar (1.25\%). Moisture amount fluctuated between 11.34and $39.04 \%$ for respectively Oukasaba and Ourous cultivars.

The date is a fruit with low content of fat; found results for the analyzed cultivars varied between 0.037 (Tazarzeit cultivar) and $0.113 \%$ (Delat cultivar). The level of lipid for Ourous and Delat cultivars was in agreement with those obtained by Al-Harrasi et al. (2014) for Naghal and Qushbu Maan of Omani date cultivars.

The 5-hydroxymethyl-2-furfural (HMF) is generally not present in fresh food, but it is naturally produced in food containing a high level of carbohydrates. HMF is the product of different reactions involving various precursors and intermediates such as carbohydrates, amino acids, vitamins, etc. (Anese and Suman, 2013). Analyzed cultivars exhibited large variations; Ouaouchet cultivar had relatively high HMF content (0.62 $\mathrm{mg} / 100 \mathrm{~g} \mathrm{DM}$ ) that probably due to their richness in reducing sugars.

Previous studies have already determined high quantities of HMF in several types of dried fruits; Rahimzadeh et al. (2014) for example obtained contents ranged between 80 and $8569 \mathrm{mg} / \mathrm{kg}$ from numerous dried fruits including date $(100 \mathrm{mg} / \mathrm{kg})$, fig $(159 \mathrm{mg} / \mathrm{kg})$, apricot $(838 \mathrm{mg} / \mathrm{kg})$, etc. The differences between these results may be due to the species, cultivar, drying procedure, storage conditions.

About 500 variable amino acids exist in nature, but only 20 constitutes the building blocks of proteins (Oancea and Formaggio, 2008). The percentage of nitrogen varied in most from 0.1 to $1.5 \%$ in fruits of which 35 to $75 \%$ is represented by protein. The amino acid profile is typical and can be used for the characterization of a fruit product (Belitz et al., 2009). The free amino acid contents of date fruits are shown in Figure1. ANOVA indicated significant differences $(p<0.05)$ between studied date cultivars. The contents ranged from 0.58 to $1.47 \mathrm{~g} / 100 \mathrm{~g}$ DM; Oukasaba contained a significantly high content of FAA. The determination of FAA contents in fruits and vegetables has been the subject of only a few investigations. The phytochemical screening studied by Birlangi (2016) has revealed the presence of eight essential amino acids and five non-essential amino acids in different cultivars of date palm fruits from the Middle-East region.
The analysis of proline content showed that the fruits Oukasaba cultivar contains a high concentration $(0.23 \mathrm{~g} / 100 \mathrm{~g} \mathrm{DM})$. Comparing with our findings, Assirey (2015) obtained slightly lower proline contents for Sudanese dates (0.09$0.15 \mathrm{~g} / 100 \mathrm{~g} \mathrm{DM})$.

The dates are not concentrated on protein, but they contain more protein than other fruits. The average protein concentrations of the studied date cultivars determined with the Bradford method is given in Figure 1. The studied cultivars present the lowest percentages of protein in comparison with the data reported in previous studies. Significant variations were shown between cultivars. The highest protein content was recorded to Tazizaout cultivar $(0.47$ $\mathrm{g} / 100 \mathrm{~g} \mathrm{DM})$ and the lowest one is attributed to Delat $(0.31 \mathrm{~g} / 100 \mathrm{~g} \mathrm{DM})$. The protein content of Tunisian date cultivars (Saafi et al., 2008) is higher than the values obtained in the present investigation. These results could be attributed to cultivar variations, environmental conditions and/or analysis methods.

Date fruit are characterized by a high content of carbohydrates, which represent the main components. These sugars are mainly reducing carbohydrates (glucose, fructose, mannose, and maltose), non-reducing sugars such as sucrose and small amounts of polysaccharides (Al-Shahib and Marshall, 2003). For date cultivars of our study, total sugars content varies from 84.51 to 96.28 $\mathrm{g} / 100 \mathrm{~g}$ DM (Figure 2), which are higher than to those found previously for dates of Saudi Arabia (71-81 g/100g DM) (Assirey, 2015).

Glucose and fructose were the predominant reducing sugars in studied date cultivars with the exception of Ourous cultivar, which had large nonreducing sugars content. The presence of high levels of reducing sugars could due to the presence of important invertase activity that liberates reducing sugars from sucrose (Fayadh and AlShowiman, 1990).

Figure 2 shows that Ouaouchet has the highest content of reducing sugars $(80.45 \mathrm{~g} / 100 \mathrm{~g} \mathrm{DM})$. Moreover, the findings of this study were higher than values published by Thouri et al. (2017) for Khorkobbi and Arechti cultivars who reported that reducing sugar contents varied from 34.66 to 24.37\%; Parvin et al. (2015) analyzed three date cultivars grown in Bangladesh and reported 42 to $48 \%$ of reducing sugars. The difference between physicochemical and nutritional parameters could mainly due to cultivar variations (Agomuo and Amadi, 2018; Jolayemi, 2019). 


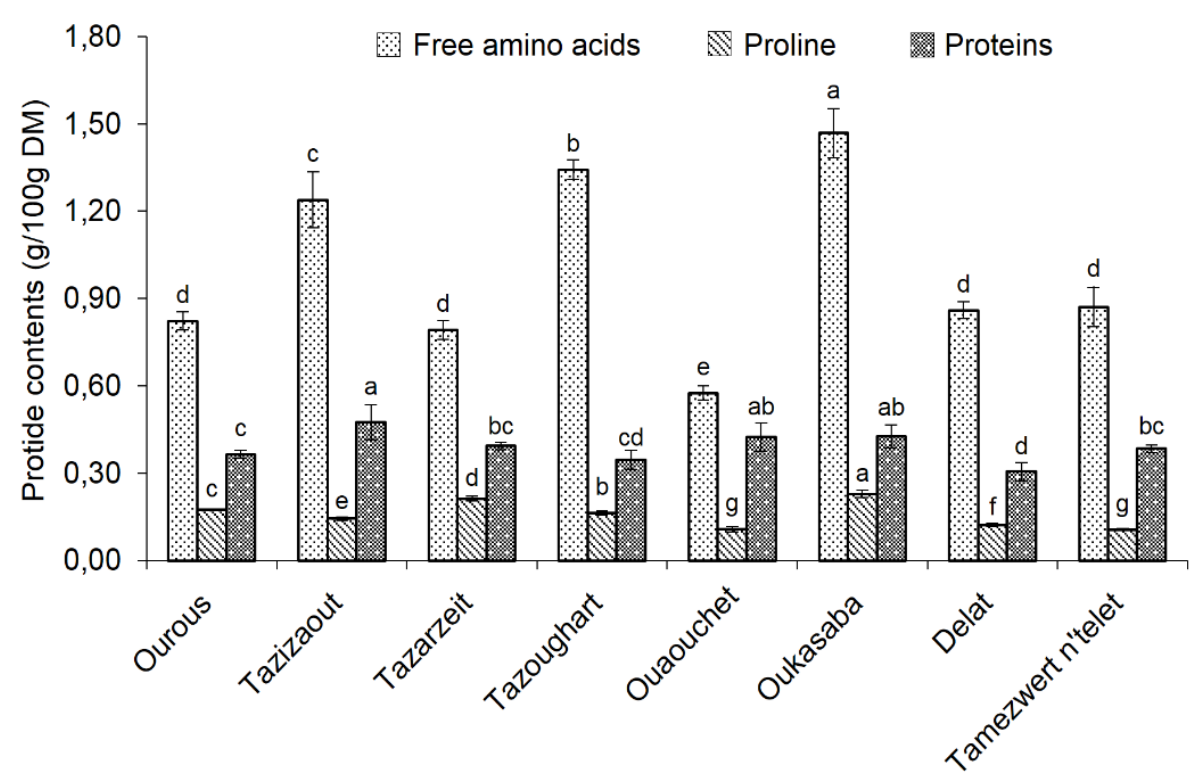

Figure 1. Free amino acid, proline, and protein contents of date fruits cultivars.

For each parameter, results with different letters are statistically different at $\mathrm{p}<0.05$ (ANOVA-LSD test)

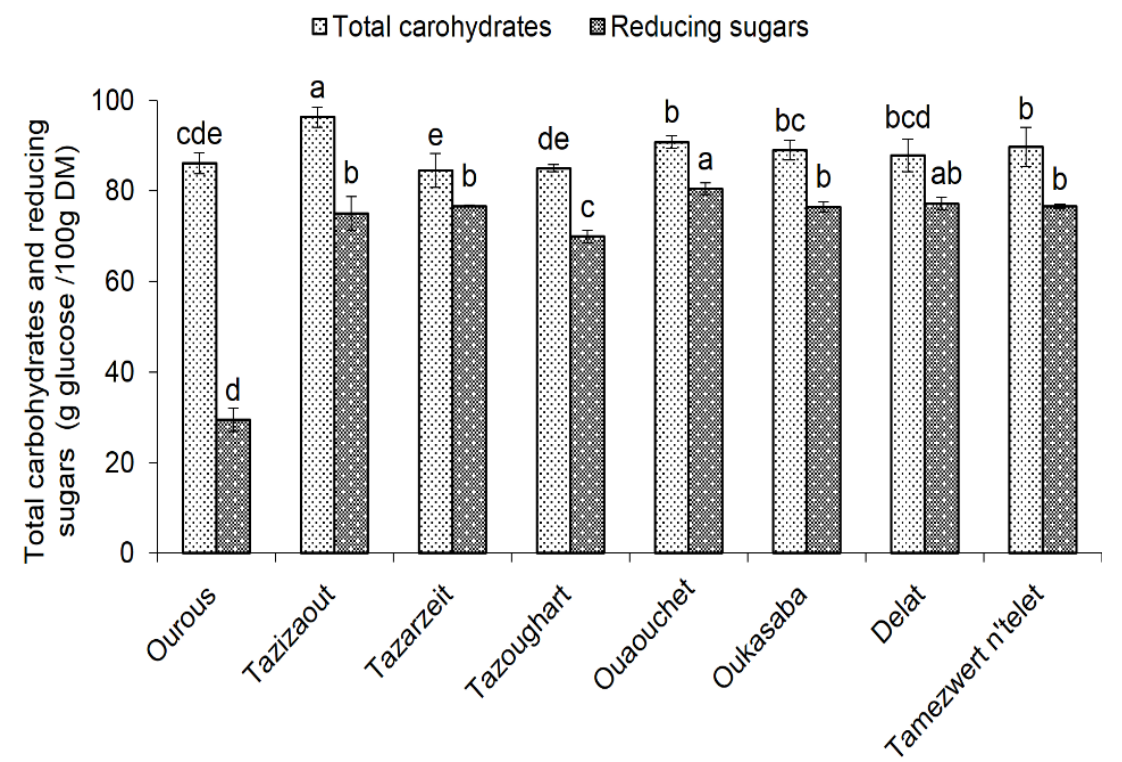

Figure 2. Total carbohydrates and reducing sugars contents of date fruits cultivars.

For each parameter, results with different letters are statistically different at $p<0.05$ (ANOVA-LSD test)

\section{Principal component analysis (PCA)}

The PCA was run using all measured physicochemical and morphological attributes in the objective to reduce the multivariate data to a two-dimensional presentation. Data exploration via Component matrix for attributes of date cultivars for the first two principal factors (PC) was showed in Table 3. For the two retained factors, the first one (PC1) explained 23\% and had characteristics with a high contribution of seed \% (-0.91), seed \%/ fruit weight (-0.91), and flesh/seed weight (0.90). The second component (PC2) explained 20\% and represented by fruits length $(-0.89)$ and weight (-
PCA indicated specific and characteristic trends in different cultivars of date, which confirms the importance of multivariate analysis for the determination of possible grouping among the studied date cultivars.

$0.80)$, proteins $(0.74)$, and fruit length/ width (0.72 ). The cumulative variance is approximately $42 \%$, which indicates that the date fruit cultivars are not well distinguished by their nutritional value and morphological characteristics. 
Table 3. Component matrix for chemical and morphological attributes of eight date cultivars for the first two principal components (PC) and the percentage variance accounted for each component.

\begin{tabular}{|l|c|c|}
\hline \multicolumn{1}{|c|}{ Attribute } & PC1 & PC2 \\
\hline Hydroxymethylfurfural & 0.380 & 0.055 \\
\hline Free amino acids & -0.443 & 0.241 \\
\hline Proline & -0.128 & 0.431 \\
\hline Proteins & 0.240 & 0.735 \\
\hline Total carbohydrates & 0.263 & 0.215 \\
\hline Reducing sugars & -0.609 & 0.278 \\
\hline Hydrogen potential & 0.174 & 0.083 \\
\hline Titratable acidity & -0.269 & 0.082 \\
\hline Total soluble solids & 0.334 & 0.306 \\
\hline Ash & 0.398 & 0.099 \\
\hline Lipids & -0.170 & -0.406 \\
\hline Moisture & -0.314 & 0.269 \\
\hline Fruit weight & 0.227 & -0.804 \\
\hline Flesh weight & 0.343 & -0.692 \\
\hline Seed weight & -0.664 & -0.690 \\
\hline Fruit length & 0.309 & -0.885 \\
\hline Fruit width & -0.466 & -0.167 \\
\hline Seed \% & -0.909 & -0.165 \\
\hline Seed \%/fruit weight & -0.910 & -0.161 \\
\hline Flesh/fruit weight & 0.139 & 0.131 \\
\hline Flesh/seed weight & 0.896 & 0.161 \\
\hline Fruit length/width & 0.479 & -0.719 \\
\hline Variance explained (\%) & 22.650 & 19.506 \\
\hline Cumulative variance (\%) & 22.650 & 42.156 \\
\hline
\end{tabular}

The graphical representation of eight date cultivars projected on the plane 1-2 of the principal component was showed in Figure 3. The distribution and the dispersion of different cultivars through the plan formed by both principal axes based on the physicochemical and morphological parameters of fruits indicate characteristic variations of studied date cultivars. From the third group, Tazarzeit cultivar was relatively isolated from other cultivars.

The results reported by Elshibli and Korpelainen (2009) assessed the variation of fifteen cultivars in soft and dry types of the Sudanese date palm, PCA was performed on the basis of the chemical and morphological parameters of fruits and tree morphology. The results showed that the use of a combination of the different characters allows distinguishing the different cultivars. However, in our study, PCA applied for the studied date fruits revealed that only Ourous and Delat cultivars can be distinguished unlike to the other cultivars.

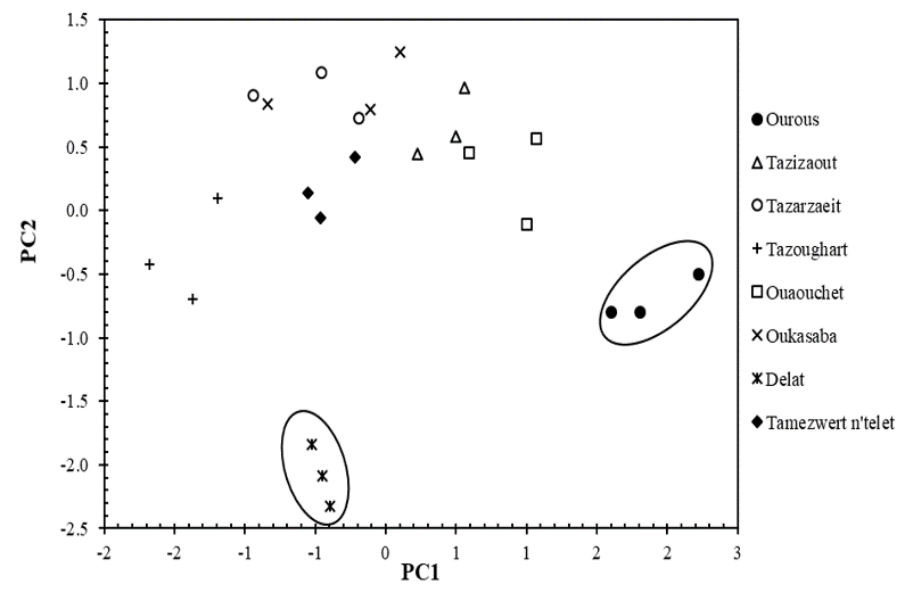

Figure 3. Dispersion of eight date fruits cultivars in the bi-plot of principal component analysis based on 22 marker systems of characterization, including fruit morphology and physicochemical characters of fruit

\section{CONCLUSIONS}

In overall, our findings provided insights into the composition and nutritional value of eight date cultivars growing in M'zab oasis (Algeria). Cultivar strongly induced variations on the different analyzed parameters; regarding the physicochemical and morphological characteristics, significant differences are recorded between the investigated date cultivars. Our results revealed that all date cultivars make an essential nutrient and valuable richness food with great potential health benefits. The date cultivars contain a higher content of amino acids, carbohydrates and reducing sugars. The Principal component analysis revealed the relationships between different cultivars based on physicochemical and morphological parameters. PCA plot showed that the Ourous and Delat cultivars have specific characteristics that allowed their distinction from other cultivars. 


\section{ACKNOWLEDGEMENTS}

This research was supported by the Algerian Ministry of Higher Education and Scientific Research as well as the «Laboratoires Hors Murs», Montpellier, France. The authors are also thankful to Mr. Boullahouat N. and all persons who have provided the date fruit samples particularly Nourredine.

\section{REFERENCES}

1. Abbès, F., Bouaziz, M. A., Blecker, C., Masmoudi, M., Attia, H. \& Besbes, S. (2011). Date syrup: effect of hydrolytic enzymes (pectinase/cellulase) on physico-chemical characteristics, sensory and functional properties. LWT-Food Sci Technol, 44(8), 1827-1834. DOI. 10.1016/j.lwt.2011.03.020

2. Agomuo, E. \& Amadi, P. (2018). Nutritional Properties of Oils from Various Parts of Three Varieties of Pears Consumed in South East Nigeria. Acta Universitatis Cibiniensis. Series E: Food Technology, 22(2), 3-12. DOI. https://doi.org/10.2478/aucft-2018-0007

3. Ahmed, I. A., Ahmed, A. W. K. \& Robinson, R. K. (1995). Chemical composition of date varieties as influenced by the stage of ripening. Food Chem, 54(3), 305-309. DOI. 10.1016/0308-8146(95) 00051-J

4. Al Tamim, E. A. (2014). Comparative study on the chemical composition of Saudi Sukkari and Egyptian Swei date palm fruits. J Amer Sci, 10(6), 149-153.

5. Al-Farsi, M., Alasalvar, C., Al-Abid, M., Al-Shoaily, K., Al-Amry, M. \& Al-Rawahy, F. (2007). Compositional and functional characteristics of dates, syrups, and their by-products. Food Chem, 104(3), 943-947.DOI. 10.1016/j.foodchem.2006.12.051

6. Al-Harrasi, A., Rehman, N. U., Hussain, J., Khan, A. L., Al-Rawahi, A., Gilani, S. A., Al-Broumi M. \& Ali L. (2014). Nutritional assessment and antioxidant analysis of 22 date palm (Phoenix dactylifera) varieties growing in Sultanate of Oman. Asian Pac J Trop Med, 7, S591-S598.

DOI. 10.1016/S1995-7645(14) 60294-7.

7. Al-Shahib, W. \& Marshall, R. J. (2003). The fruit of the date palm: its possible use as the best food for the future? Inter J Food Sci Nutr, 54(4), 247-259. DOI. 10.1080/09637480120091982

8. Amira, E. A., Guido, F., Behija, S. E., Manel, I., Nesrine, Z., Ali, F., Mohamed, H., Noureddine H. A. \& Lotfi A. (2011). Chemical and aroma volatile compositions of date palm (Phoenix dactylifera L.) fruits at three maturation stages. Food Chem, 127(4), 1744-1754.

DOI. 10.1016/j.foodchem.2011.02.051

9. Anese, M. \& Suman, M. (2013). Mitigation strategies of furan and 5-hydroxymethylfurfural in food. Food Res Int, 51(1), 257-264. DOI. 10.1016/j.foodres.2012.12.024

10. Assirey, E. A. R. (2015). Nutritional composition of fruit of 10 date palm (Phoenix dactylifera L.) cultivars grown in Saudi Arabia. J Taibah Univ Med Sci, 9(1), 75-79. DOI. 10.1016/j.jtusci.2014.07.002

11. Bates, L., Waldren, R. \& Teare, I. (1973). Rapid determination of free proline for water-stress studies. Plant and soil, 39(1), 205-207. DOI.10.1007/BF00018060

12. Belitz, H., Grosch, W. \& Schieberle, P. (2009). Fruits and fruit products. In H. D. Belitz, W. Grosch \& P. Schieberle (Eds.), Food chemistry (pp. 807-861). Springer: Berlin, Heidelberg.

DOI. 10.1007/978-3-540-69934-7_19

13. Birlangi, L. (2016). Screening of amino acid constituents from date palm fruits. Int J Bioassays, 5(10), 4972-4976. DOI.10.21746/ijbio.2016.10.0011

14. Bradford, M. M. (1976). A rapid and sensitive method for the quantitation of microgram quantities of protein utilizing the principle of protein-dye binding. Anal Biochem, 72(1-2), 248-254. 10.1016/00032697(76) 90527-3

15. Chandrasekaran, M. \& Bahkali, A. H. (2013). Valorization of date palm (Phoenix dactylifera) fruit processing by-products and wastes using bioprocess technology-Review. Saudi J Biol Sci, 20(2), 105120. DOI. 10.1016/j.sjbs.2012.12.004

16. Dubois, M., Gilles, K. A., Hamilton, J. K., Rebers, P. t. \& Smith, F. (1956). Colorimetric method for determination of sugars and related substances. Anal Chem, 28(3), 350-356. DOI. 10.1021/ac60111a017

17. Elshibli, S. \& Korpelainen, H. (2009). Biodiversity of date palms (Phoenix dactylifera L.) in Sudan: chemical, morphological and DNA polymorphisms of selected cultivars. Plant Genet Resour, 7(2), 194203. DOI. 10.1017/S1479262108197489

18. FAOSTAT. (2018). Food and agriculture organization of the United Nations. Retrieved March 8, 2019, from http://faostat.fao.org/site/339/default.aspx. 
19. Fayadh, J. \& Al-Showiman, S. (1990). Chemical composition of date palm (Phoenix dactylifera L.). $J$. Chem. Soc. Pak, 12(1), 84-103.

20. Ghnimi, S., Umer, S., Karim, A. \& Kamal-Eldin, A. (2017). Date fruit (Phoenix dactylifera L.): An underutilized food seeking industrial valorization. NFS J, 6, 1-10. DOI. 10.1016/j.nfs.2016.12.001

21. Hesami, A. \& Abdi, G. (2010). Effect of some plant growth regulators on physiochemical characteristics of date palm (Phoenix dactylifera L. cv. Kabkab) fruit. American-Eurasian J Agric \& Environ Sci, 7(3), 277-282.

22. ISO 750. (1998). Determination of titratable acidity: fruit and vegetable products. Genève, Suisse: International Standard Organization.

23. Jahromi, M. K., Jafari, A., Keyhani, A., Mirasheh, R. \& Mohtasebi, S. (2007). Some physical properties of date fruit (cv. Lasht). Agric Eng Int CIGR J, FP 07 019. Vol. IX. 1-7.

24. Lemine, F. M. M., Samb, A., Zein el Abidine, O. B., Ahmed, M. V. O. M., Djeh, T.-K. O. \& Boukhary, A. O. M. S. O. (2014). Assessment of physicochemical diversity in fruit of Mauritanian date palm (Phoenix dactylifera L.) cultivars. African $J$ Agric Res, 9(28), 2167-2176. DOI. 10.5897/AJAR2013.8250

25. Miller, G. L. (1959). Use of dinitrosalicylic acid reagent for determination of reducing sugar. Annal Chem, 31(3), 426-428.

DOI. $10.1021 / \mathrm{ac} 60147 \mathrm{a} 030$

26. Mrabet, A., Ferchichi, A., Chaira, N. \& Mohamed, B. S. (2008). Physico-chemical characteristics and total quality of date palm varieties grown in the southern of Tunisia. Pakistan J Biol Sci, 11(7), 10031008. DOI. $10.3923 /$ pjbs.2008.1003.1008

27. Myhara, R. M., Karkalas, J. \& Taylor, M. S. (1999). The composition of maturing Omani dates. J Sci Food Agric, 79(11), 1345-1350. DOI. 10.1002/(SICI) 1097-0010

28. Oancea, S. \& Formaggio, F. (2008). Biological role of D-a-amino acids and their occurence in foodstuffs. Acta Universitatis Cibiniensis Series E: Food Technology, 12(1), 3-12.

29. Parvin, S., Easmin, D., Sheikh, A., Biswas, M., Sharma, S. C. D., Jahan, M. G. S., Islam, M. A., Roy, N. \& Shovon, M. S. (2015). Nutritional analysis of date fruits (Phoenix dactylifera L.) in perspective of Bangladesh. Am J Life Sci, 3(4), 274-278. DOI. 10.11648/j.ajls.20150304.14

30. Rahimzadeh, N., Alizadeh, M. \& Ghaemmaghami Hezaveh, S. J. (2014). Estimated bioaccessibility to 5-hydroxymethylfurfural from frequently consumed dried fruits in Iran. $J$ Chem Health Risks, 4(3), 1523. DOI. 10.22034/JCHR.2018.544071a

31. Rastegar, S., Rahemi, M., Baghizadeh, A. \& Gholami, M. (2012). Enzyme activity and biochemical changes of three date palm cultivars with different softening pattern during ripening. Food Chem, 134(3), 1279-1286. DOI. 10.1016/j.foodchem.2012.02.208

32. Saafi, E. B., Trigui, M., Thabet, R., Hammami, M. \& Achour, L. (2008). Common date palm in Tunisia: chemical composition of pulp and pits. Inter J Food Sci Technol, 43(11), 2033-2037. 10.1111/j.1365-2621.2008.01817.x

33. Saeed, I. K., El-Rauof, F. A. \& Dawoud, H. (2015). Physico-chemical Evaluation of Some Introduced Date Fruits cultivars grown under Sudanese conditions. Int J Appl Sci Biotechnol, 3(4), 731-736. DOI. 10.3126/ijasbt.v3i4.13996

34. Shar, G. Q., Memon, A. H., Makhija, P. M. J., Sahito, S. B. \& Jatoi, W. B. (2012). Physico-Chemical Characteristics of Pollinated and Non Pollinated Date Fruit of District Khairpur, Sindh, Pakistan. Pakistan J Anal Environ Chem, 13(2), 107-117

35. Singh, V., Guizani, N., Al-Alawi, A., Claereboudt, M. \& Rahman, M. S. (2013). Instrumental texture profile analysis (TPA) of date fruits as a function of its physico-chemical properties. Indus Crop Prod, 50, 866-873. DOI. 10.1016/j.indcrop.2013.08.039

36. Sulieman, A. M., Abd Elhafise, I. \& Abdelrahim, A. (2012). Comparative study on five Sudanese date (Phoenix dactylifera L.) fruit cultivars. Food Nutr Sci, 3(2), 1245-1251. DOI. 10.4236/fns.2012.39164.

37. Thouri, A., Chahdoura, H., El Arem, A., Hichri, A. O., Hassin, R. B. \& Achour, L. (2017). Effect of solvents extraction on phytochemical components and biological activities of Tunisian date seeds (var. Korkobbi and Arechti). BMC complement alternat med, 17(1), 248. DOI. 10.1186/s12906-017-1751-y

38. White, J. J. (1979). Spectrophotometric method for hydroxymethylfurfural in honey. J Assoc Off Anal Chem 62(3), 509-514. 
39. Yemm, E., Cocking, E. \& Ricketts, R. (1955). The determination of amino-acids with ninhydrin. Analyst, 80(948), 209-214. DOI. 10.1039/an9558000209 